\title{
EFFICIENCY OF GOVERNMENT SPENDING FOR HUMAN DEVELOPMENT SOME DISTRICTS IN CENTRAL JAVA DURING 2008-2012
}

\author{
Hastarini Dwi Atmanti ${ }^{* 1}$
}

\author{
${ }^{1}$ Universitas Diponegoro
}

\begin{abstract}
Human development is a good indicator to measure the progress of a nation. Welfare of a nation measured not only from the gross domestic product, but also from the human development aspect, which include education and public health. The paper represented education and health aspect by the Human Development Index (HDI) while the economic performance is reflected by the value of Purcashing Power Parity (PPP) index. This study analyzes the efficiency of government spending on human development using Data Envelopment Analysis (DEA). The study shows that the level of efficiency of government spending on human development in some districts in Central Java during 2008 - 2012 is more than 90\%.
\end{abstract}

Keywords: Government Spending, Human Development, Efficiency

JEL Classification: D61

To cite this document: Atmanti, H. D. (2016). Efficiency of Government Spending for Human Development Some Districts in Central Java During 2008-2012. JDE (Journal of Developing Economies), 1(2). 101-106

\author{
ARTICLE INFO \\ Received: February $21^{\text {st }}, 2016$ \\ Revised: September $5^{\text {th }}, 2016$ \\ Accepted: November $1^{\text {st }}, 2016$ \\ Online: December $24^{\text {th }}, 2016$ \\ ${ }^{*}$ Correspondence: \\ Hastarini Dwi Atmanti \\ E-mail: \\ hastarini_dwi_atmanti@yahoo.com
}

\section{Introduction}

Human capital theory was first popularized by Theodore Schultz in the 1960s. According to Schultz (1961), there are five ways in measuring the development of human capital, namely: (i) Health services and facilities, generally interpreted to include all the expenses thataffect life expectancy, strength and stamina, energy and vitality of the community; (ii) Exercises include internships organized by the company; (iii) Formal education such as elementary, junior and senior high school; (iv) Learning programs for adults who are not organized by the company include theextension program, especially in agriculture; (v) Individuals migration and family to adaption themselves to change in employment.

High quality human capital can be treated as the wheel of economic growth. The quality of human resources for developing countries is an important factor in the effort to catch up with the development of other countries. Improved health and education is an investment value for the family to get out of the vicious circle of poverty trap.

Education and health are fundamental national development goals. Health is at the core of welfare, and education is essential to reach the precious life. Both are fundamental to establish a broader human capabilities that are at the core of the meaning of development. At the same time, education played a major role in shaping the ability of developing countries to absorb modern technology and to develop the capacity to create growth and sustainable development. Furthermore, health is a prerequisite for increased productivity, while the educa-

JDE (Journal of Developing Economies) p-ISSN: 2541-1012; e-ISSN: 2528-2018 DOI: http://dx.doi.org/10.20473/jde.v1i2.3695 
tional success also rests on good health. Therefore, health and education can also be seen as a vital component of growth and development, as input aggregate production function. His dual role as both input and output lead to health and education is very importantin economic development. (Todaro and Stephen, 2006)

The success of a national development program is not only as marked by the high rate of economic growth but also includes human quality. The Human Development Index is a tool to assess the quality of human development, both in terms of its impact on a person's physical condition (health and welfare) as well as non-physical (intellect). Human Development Index (HDI) is a measure of comparison of life expectancy, literacy, education and standard of living for all countries around the world, which were presented by the three dimensions of long and healthy life, knowledge and a decent life (BPS, 2008). Nationally, in 2013, the HDI of Central Java is ranked 16 among the 34 provinces.

Efforts to achieve a better life, should be assisted by the government through the allocation of government spending on education and health sectors. An increase in the allocation of government spending in the public sector will also increase the productivity of the population. Increased productivity can improve human development which in turn will affect the poverty reduction. The poverty level of Central Java is ranked 7th nationally in 2013, where the value is higher than the national level. According to Widodo et al. (2012) indicators of human development, and poverty indicators inCentral Java province, (b the average percentage of the allocation of government spending public sector on educationin 35 districts or cities in Central Java province in 2007 is only 4.91 per cent and 5.41 percentin 2008. While the average percentage allocation of government spending areas of the public sector on health in 35 districts in Central Java province in 2007 and 2008 is only 1.27 percent and 1.37 percent, respectively. The allocation of education spending is higher than the allocation of health spending because it is in accordance with the mandate of the law. The Government guarantees the right of every citizen to get an education. The constitution states that every citizen is entitled to education. The government requires every citizen to participate in primary education, on the other hand it compulsary to the government to allocates 20 percent of state and local budgets for education (on the 4th amandments of UUD 1945). The budget allocation is expected to meet the needs associated with improving the quality of education.

The empirical results suggest the importance of sectoral spending. It seems that a countries with a high level of corruption tends to have a very ineffective bureaucracy, this is moreover leads to an ineffective public health spending. conversely, public expenditure on primary education increased tends to be more effective in raising achievement in basic education in countries with good governance (Rajkumar and Swaroop 2007 in Prasetyo \& Zuhdi (2013).

An effort to improve the quality of human capital, the principle efficiency of government spending should obviously be taken into account. If high levels of efficiency, the expenditure can be calculated as accurately as possible according the intended target and eventually is expected to improve the human quality. The aim of the study is to analyze the efficiency of government spending in some districts in Central Java during 2008-2012.

\section{Research Methods}

The Data Envelopment Analysis (DEA) is designed specificaly to measure the relative efficiency of a unit of economic activity or Decision Making Units (DMUs) which uses a lot of input and outputs (multi-input multi-output), with different units that are difficultto be handled perfectly by the other efficiency measurement analysis techniques (Mahlberg \& Obersteiner, 2012).

Efficiency that is measured by DEA analysis has the different character from the con- 
cept of efficiency in general. First, the efficiency of which is measured is of a technical analysis, not economic. The DEA analysis only takes into account the absolute value of a variable. The basic unit of measurement that reflects the economic value of each variablesuch as price, weight, length, content and others are not considered. Therefore, it is possible acalculation pattern combination of various variables with different units. Second, the value of the efficiency of the money generated is relative, or only applicable in the comparable set of the DMU (Nugroho, 1995).

The study used secondary data published by BPS (Indonesia Statistic Agency) and Direktorat Jenderal Perimbangan Keuangan Kementerian Keuangan RI (Ministry of Finance) on the yearly basis during the period of 2008 to 2012. Input variables are the realization of public expenditure on health per capita and actual government spending on education per capita. These variables in millions of rupiah. Output variable is the Human Development Index (HDI) with units per cent. This variable refers to the study of Mahlberg \& Obersteiner, 2012; Vierstraete, 2012; and Prasetyo \& Zuhdi, 2013.

This study analyzed 18 cities from 35 districts in Central Java during 2008-2012 as follows: 1) Banjarnegara; 2) Banyumas; 3) Blora; 4) Boyolali; 5) Grobogan; 6) Kebumen; 7) Klaten; 8) Kudus; 9) Magelang; 10) Pati; 11) Pekalongan; 12) Pemalang; 13) Rembang; 14) Sragen; 15) Tegal; 16) Wonogiri; 17) Wonosobo; and 18) Pekalongan.

The assumptions of DEA in this study is output oriented and VRS (Variable Ruturn to Scale). The measurement efficiency of government expenditure to human development by DEA formulated as follows:

$$
E_{k}=\sum_{r=1}^{s} u_{r k} . Y_{r k}
$$

With no restrictions or constraints:

$$
\begin{gathered}
\sum_{r=1}^{s} u_{r k} . Y_{r j}-\sum_{i=1}^{m} v_{i k} . X_{i j} \leq 0 ; j=1, \ldots, n \\
\sum_{i=1}^{m} v_{i k} . X_{i k}=1 \\
u_{r k} \geq 0 ; r=1, \ldots, s \\
v_{i k} \geq 0 ; i=1, \ldots, m
\end{gathered}
$$

Where :
$Y_{r k}$
: The amount of output $r(\mathrm{HDI})$ of districts.
$X_{i j}$
: The amount of input $\mathrm{i}$ (spending on health per capita andspending for education per capita) required of districts.
$Y_{r j}$
$X_{\mathrm{ik}}$
: The amount of output $r$ (IPM) of districts.
: The amount of input $\mathrm{i}$ (spending on health per capita andspending for education per capita) required of districts.
S
: The number of districts were analyzed.M : The number of input.
$\mathrm{u}_{\mathrm{rk}}$
: Weighted of output $r$ in each districts.
$v_{\text {ik }}$
: Weighted weight of input $\mathrm{i}$ in each districts.
$E_{k}$
: Optimized value as an indicator of the relative efficiency ofdistricts. 


\section{Result and Discussion}

This study uses Banxia Frontier Analyze 3 to analyze the efficiency of government expenditure to human development some districs in Central Java during 2008 - 2012. The summary of the results of the analysis are as follows:

Table 1: The Efficient Districts

\begin{tabular}{cl}
\hline Year & \multicolumn{1}{c}{ District } \\
\hline $\mathbf{2 0 0 8}$ & Wonosobo, Grobogan, Banyumas, Klaten, Pekalongan City \\
\hline $\mathbf{2 0 0 9}$ & $\begin{array}{l}\text { Kebumen, Klaten, Rembang, Pekalongan (district), Wonosobo,Banyumas, Peka- } \\
\text { longan City, Pati, Kudus }\end{array}$ \\
\hline $\mathbf{2 0 1 0}$ & Pekalongan City, Grobogan, Pati, Klaten, Banyumas \\
\hline $\mathbf{2 0 1 1}$ & Pemalang, Tegal, Magelang, Pati, Pekalongan City, Klaten \\
\hline $\mathbf{2 0 1 2}$ & Grobogan, Magelang, Pekalongan City, Klaten \\
\hline
\end{tabular}

Source: Author's calculation

Table 1 shows that the efficiency of government expenditure to human development in Central Java is still low. These results are consistent with the study of Widodo et al. (2012) indicators of human development, and poverty indicators inCentral Java province, (b, which indicated that the allocation of expenditure or government spending on education and health in Central Java is still low. As the level of government spending allocation on education and health is very likely affect the human capital development (Prasetyo \& Zuhdi, 2013), the low allocation of government spending will inhibit the development of human capital.

Table 2: Efficiency Achievement

\begin{tabular}{lrrrrr}
\hline \multicolumn{1}{c}{ District } & \multicolumn{1}{c}{$\mathbf{2 0 0 8}$} & \multicolumn{1}{c}{$\mathbf{2 0 0 9}$} & \multicolumn{1}{c}{$\mathbf{2 0 1 0}$} & \multicolumn{1}{c}{$\mathbf{2 0 1 1}$} & \multicolumn{1}{c}{$\mathbf{2 0 1 2}$} \\
\hline Banjarnegara & 94.55 & 95.86 & 94.84 & 95.37 & 95.01 \\
\hline Banyumas & 100 & 100 & 100 & 99.62 & 99.06 \\
\hline Blora & 95.40 & 94.77 & 96.67 & 96.67 & 95.75 \\
\hline Boyolali & 99.61 & 96.56 & 95.83 & 95.95 & 95.69 \\
\hline Grobogan & 100 & 99.07 & 100 & 97.78 & 100 \\
\hline Kebumen & 96.23 & 100 & 96.95 & 97.45 & 96.76 \\
\hline Klaten & 100 & 100 & 100 & 100 & 100 \\
\hline Kudus & 98.80 & 100 & 99.16 & 99.67 & 99.07 \\
\hline Magelang & 97.94 & 99.97 & 99.64 & 100 & 100 \\
\hline Pati & 99.04 & 100 & 100 & 100 & 99.67 \\
\hline Pekalongan (district) & 97.79 & 100 & 97.49 & 97.30 & 97.36 \\
\hline Pemalang & 97.43 & 97.81 & 97.60 & 100 & 96.53 \\
\hline Rembang & 97.49 & 100 & 97.40 & 97.09 & 96.92 \\
\hline Sragen & 95.38 & 98.87 & 95.77 & 95.96 & 95.90 \\
\hline Tegal & 96.30 & 97.38 & 99.04 & 100 & 98.92 \\
\hline Wonogiri & 96.59 & 98.72 & 96.37 & 96.70 & 97.14 \\
\hline Wonosobo & 100 & 100 & 97.61 & 96.60 & 95.37 \\
\hline Pekalongan City & 100 & 100 & 100 & 100 & 100 \\
\hline
\end{tabular}

Source: Author's calculation

Klaten and Pekalongan City achieve the highest efficiency during years of analysis (see Table 2). The achievement of the efficiency in all the years of observation showed valuesabove $90 \%$. There are changes in education spending of capital expenditure into a grant expenditure in 2009 where the realization of this education grant expenditure is $100 \%$ in 2009 . Doryan 
study (2001) in Prasetyo \& Zuhdi (2013) pointed out that when the government has used the government budget to fund of primary health care and education, these sectors will bring multiple benefits to the poor, meanwhile Razmi et. al (2012) in Prasetyo \& Zuhdi (2013) indicated that the increase of spending on health and education will increase labor productivity which in turn will boost the economic growth.

In DEA analysis, the most efficient district will be regarded as the benchmark. For example, Boyolali was not efficient in 2008. Banyumas and Grobogan were benchmark for Boyolali in 2008 (see Table 3). Banyumas and Grobogan have been efficient in 2008 (see Table 1 and 2). Banyumas and Grobogan are as efficient as Wonosobo Boyolali, Klaten and Pekalongan City in 2008.

Table 3: Peer References Boyolali in 2008

\begin{tabular}{lr}
\hline Efficiency Report & Peers: 2 \\
\hline $99.61 \%$ Kab. Boyolali & References: 0 \\
\hline Peer References & \\
\hline Unit & \\
\hline Kab. Banyumas & \\
\hline Kab. Grobogan & \\
\hline
\end{tabular}

Source: Author's calculation

The returns to scale of all districts that are not efficient (according to Table 2) are increasing returns to scale. This means that it is possible to increase government spending on education and health to improve the quality of human capital. For example, Blora were not efficient in 2012, indicated by the level of efficiency on 95, $75 \%$ (see Table 4).

Table 4: Score and Improvement

\begin{tabular}{lccc}
\hline 95.75\% Kab. Blora (12) & & & \\
\hline & Actual & Target & Potential improvement \\
\hline Kesehatan/kapit & 0.15 & 0.15 & $00.00 \%$ \\
\hline Pendidikan/kapit & 0.69 & 0.69 & $00.00 \%$ \\
\hline IPM & 71.49 & 74.67 & $04.44 \%$ \\
\hline
\end{tabular}

Source: Author's calculation

Output variable (HDI) should be increased in Blora, because the actual value is below the target value. The level of government spending on health per capita and education per capita in Blora does not need any change as the achievements has met the determined target. The result of DEA anlysis tells that the performance efficiency in Blora in 2012 is increasing returns to scale. However this is not occured economically efficient, according DEA technical analysis. Our analysis concludes that the input variables can be raised, given the education and health as the basic needs of the population and the role of government was very large in this case.

\section{Conclusion}

Based on the calculation of the efficiency of government expenditure on human development for some districts in Central Java during 2008 - 2012, the results shows that the achievement of efficiency in all districts are good considering the level of its achievement, all of which exceeds 90 percent. The HDI in all districts that are inefficient showing increasing return to scale, which means that the quality of the human capital is necessary to be improved. 


\section{Suggestion}

1. This study only involved 18 districts, then the future research should include all districts in Central Java for further analysis.

2. Input variable were not only the realization of public expenditure on health per capita as well as the realization of government spending on education per capita, but also need to add other variables such as the ratio of doctors per 1000 population, student-teacher ratios in elementary, senior and high school. The components that forming the HDI such as literacy rate, life expectancy, average length of school, and the purchasing power parity to be translated need to be added to the output variable

\section{References}

BPS. (2008). Konsep Indeks Pembangunan Manusia. https://jateng.bps.go.id/subject/26/indeks-pembangunan-manusia.html\#subjekViewTab1

Mahlberg, B., \& Obersteiner, M. (2012). Remeasuring the HDI by Data Envelopement Analysis. SSRN Electronic Journal. https://doi.org/10.2139/ssrn.1999372

Prasetyo, A. D., \& Zuhdi, U. (2013). The Government Expenditure Efficiency towards the Human Development. Procedia Economics and Finance, 5. https://doi.org/10.1016/s2212$5671(13) 00072-5$

Schultz, T. W. (1961). Investment in human capital. The American economic review, 51(1), 1-17.

Todaro, M. P., \& Smith, S. C. (2006). Ekonomi Pembangunan. Jakarta: Erlangga, 58-81.

Vierstraete, V. (2012). Efficiency in human Development: a Data Envelopment Analysis. The European Journal of Comparative Economics, 9(3).

Widodo, A., Waridin, W., \& Kodoatie, J. M. (2012). Analisis Pengaruh Pengeluaran Pemerintah Di Sektor Pendidikan Dan Kesehatan Terhadap Pengentasan Kemiskinan Melalui Peningkatan Pembangunan Manusia Di Provinsi Jawa Tengah. Jurnal Dinamika Ekonomi Pembangunan, 1(1). https://doi.org/10.14710/jdep.1.1.25-42 